\title{
Determinants of Political Violence: A Study of the Literature
}

\author{
Daniel Mider \\ Instytut Badań nad Człowiekiem i Społeczeństwem im. Elżbiety Mider z d. Korzun \\ (Elizabeth Mider (de domo Korzun) Research Institute for Man and Society), \\ ul. Meander 12 m. 38, 02-791 Warszawa \\ Tel: 48-501-666-779 E-mail: d.mider@poczta.uw.edu.pl,nmt@o2.pl
}

Received: January 20, 2014 Accepted: March 8, 2014 Published: April 25, 2014

doi:10.5296/jsss.v1i2.5526 URL: http://dx.doi.org/10.5296/jsss.v1i2.5526

\begin{abstract}
Political violence is a complex phenomenon that is induced by numerous factors. The article focuses on trying to identify and organize the sources of political violence. Three groups of determinants of political violence can be distinguished on the basis of the examined social science literature. The first group of determinants of political violence - referred to as structural determinants - is examined by researchers within the social structure. Cultural patterns and norms operating within the dominant culture or subculture form the second group of sources of violence, referred to as cultural determinants of violence. The third group - individual or socio-psychological determinants of violence in politics - could be observed in individual factors, usually subjective, related to emotions.
\end{abstract}

Keywords: Sociology of violence, Political violence, Determinants of violence 


\section{Introduction}

The literature on the subject points to three groups of determinants of political violence, with researchers focusing their attention in each of these on other aspects of the social system. Firstly, researchers look for the determinants of violence in the social structure. Secondly, they consider cultural patterns and norms operating within the dominant culture or subculture as a significant source of violence. Thirdly, they point to individual factors, usually subjective, related to emotions. A significant problem in research on the determinants of violence is the fact that scholars too often focus on individual factors determining the occurrence of violence. Their relationships to each other are not sought, with the researchers usually limiting themselves to the creation of enumerative lists, with no attempts made at identifying links and correlations between them, which leads to important factors of violence being downplayed or ignored (Czyżewski, 2003, p. 214). Differences in interpretation are the result of different methodologies and paradigms existing in the three groups of determinants of political violence and also lead to significant differences in the ethical assessment of political violence.

\section{Structural Determinants of Violence in Politics}

A substantial number of researchers believe that the determinants of political violence lie in the defective system of social and political structures. Three approaches can be distinguished here. Within the first, the determinants of violence are sought by researchers in the area of relationships and power structures. This perspective is the domain of political scientists. Faulty relationships and social ties between classes, layers, and other social elements are indicated in the second approach. The third perspective looks for sources of political violence in the non-satisfaction of the objective needs of particular social groups - the central explanatory category is that of the uneven distribution of economic resources. This concept is essentially derived from the one preceding. Researchers working in the scope of the structural determinants of political violence frequently indicate that sources of violence are rooted in the particular social and political system - the system of social classes and strata, the economic system, and the political hierarchy (Apter, 1997, pp. 7-8; Burgoon, 2006).

Researchers searching for sources of political violence within the structures of power have initially indicated that political necessity is the primary determinant of violence. Political processes force activities related to violence. This view was developed, among others, by Pareto. He believed that the elite will remain the elite only if:

[...] they are ready to go to the extremes, resorting with no scruples - when need be - to force and arms; otherwise the resistance is not only effective, but may also serve, sometimes even to a large extent, the opponents.

[Pareto, 1994, p. 338].

According to Pareto it is wrong for those in power to keep both "the wolf of order and the sheep of tolerance", as it is always necessary to choose between these two values (Pareto, 1994, p. 339). In contemporary times, such a view is expressed by American neo-conservative political analyst Kagan. He notes significant differences between the practice of the use of violence in international relations by the European Union and the 
United States. The reasons for the use of force by the United States and its avoidance by the countries of the European Union are sought not only in the historical circumstances of those entities, not in a specific ideology, but in political pragmatics. This author sees the use of force to be determined only by the possibility of its application, by the current military, political and ideological potential of a given entity (Kagan, 2003, pp. 11-16). An analogous way of explanation is found in the currently developed resource mobilization theory. This includes concepts such as political theory, political process theory and political opportunity theory. They arose in the early seventies of the XX century and are aimed at clarifying the causes, course and consequences of collective action, including actions with the use of violence. Their creation and development are mainly attributable to Olson, McCarthy and Zaldow. An analysis of collective actions and social movements has been taken with the help of concepts from the resource mobilization theory by, among others, Tilly (1978), Tarrow (1998) and Gameson (1975; 1992). The basic assumption of this concept states that all social activities, including violence, are conditioned by a given level of resource aggregation. The reserves of resources include resources that are economic, temporal, communication related and human, as well as social and cultural capital of members and supporters, and legitimizing potential. In this approach, violence is seen as a conscious and considered response of a rational social actor. If leaders are able to accumulate these key resources in sufficient quantities, then the use of force is possible and has a chance of success. The concept discredits psychological factors (a sense of discontent, non-satisfaction of needs) in favor of material factors - the capacity for mobilization and the organization of resources. Critics of this approach suggest that it creates a false image of an overly rational, coldly calculating, devoid of emotions individual as an actor in political activities (Barkan \& Snowden, 2001, pp. 23-24).

Under the conditions of political violence, the role of the functioning of state structures in the generation or suppression of this phenomenon is emphasized. Democracies are systems that generate numerous mechanisms to prevent violence, including periodic elections, police procedures, court proceedings (Keane, 2004, p. 9). The fact that violence manifests itself is usually an indication of serious defects in the democratic processes and structures. It generally indicates that a high level of legitimacy is correlated with low levels of violence (Bill, 1973, p. 230; Coser, 1967, p. 96; Hughes 2004, p. 7; Lupsha \& MacKinnon, 1973, pp. 7-8; Von der Mehden, 1973, p. 74). Lupsha and Mackinnon analyzed 1404 cases of the use of violence for political reasons. The sample was chosen on the basis of reports on this subject published in the press and institutions involved in monitoring national events in the US press and research institutions; with the years 1965-1971 as the cut off points. In this approach violence is, in general, seen as a form of protest, caused by blocked channels of political participation (Barkan \& Snowden, 2001, p. 10). It is pointed out that if people cannot express their needs through legitimate channels of political participation, they communicate them by force.

An excessive distance between the state and the citizens is among the important determinants of violence. This phenomenon leads to a pathological political culture - the creation of the so-called social clash ethics. This is a permanent situation of bilateral mutual blocking. Violence can also be a "cry of those lost in regulations" - excessive institutionalization and 
bureaucratization on the part of the state may be perceived as a form of violence and ultimately generate the use of force by its citizens (Peyrefitte, 1982, pp. 144-145, 148, 149, 151). In the course of empirical research on violence around the world the following determinants of political violence have been identified: violation of the democratic process (violation of human rights, violation of legal norms by the state, corruption), political instability (sudden changes in governance), the ethnic composition of the ruling group differing significantly from the rest of society (political and economic power distributed according to an ethnic, religious or social key), the deterioration of public services (a significant decline in the range and effectiveness of public social security allowing for the provision of a universal minimum standard of services). Globalization processes are considered to be important determinants of violence. Globalization leads to inequality through increases in privatization, the declining role of the nation-state, the collapse of social services, the reduction in the size of the public sector. Inequality, in turn, raises the degree of competition for resources, increases the availability of firearms and the weakened state is not able to cope with these problems and challenges, and it is more likely to employ force as a result (Krug et al., 2002, pp. 220-221). Violence on the part of the state is perceived as an important factor generating violence - a concept of counter-violence has even been created to describe more or less organized responses of citizens in response to the use of force by state institutions (Piotrowski, 2003, p. 160). The type of political system has a great influence on the generation of political violence - the more rigid the political structure, the greater the likelihood that political changes will take place through the use of violence. Smelser and Swedberg (1994) assign first rate importance to this factor stressing that the likelihood of violence in democracies is much smaller than in authoritarian and totalitarian systems. Democracies have numerous institutions that allow for conflict resolution without violence, while such solutions are absent in non-democratic political systems (Barkan \& Snowden, 2001, pp. 10, 21).

The determining factor of political violence is the system of social relations between classes, layers and other social groups. Reflections on this subject can be found in Marx, Simmel and Dahrendorf (Grimshaw, 1972, pp. 39, 41-44). Coser (1967, p. 55) stressed that deviation is unevenly distributed within the social structure; violence is in general committed by people who have fallen in the Habermas "mills of marginalization" (Czyżewski, 2003, p. 221). Ethnicity, class position and professional status are factors determining the use of violence (Coser, 1967, p. 57). As a result of factors such as urbanization and industrialization, individuals lose their ties with social groups and society as a whole, they become alienated and consequently susceptible to ideologies that inspire the use of violence. Błuszkowski (2007, pp. 99, 100, 104-106) links the use of violence with globalization processes and failure or inadequacy of political and social institutions in relation to the expectations, aspirations and needs of individuals and groups, and thus the phenomenon of institutional negative deviation. The incompatibility between the needs and expectations of individuals and groups, the closing of communication channels between the ruled and the rulers may in effect lead to a transgression of social norms, including the use of force. Such a view was clearly expressed by Czarnowski (1982, pp. 199-200, 210), according to whom the appearance of a sufficient number of individuals deprived of a class, with no set social status, perceived as unnecessary 
from the point of view of material and intellectual production, and seeing themselves as such, is considered a sufficient and necessary factor for the emergence of violence. Violence is triggered and caused by the resentment of these redundant individuals. American political scientist Skocpol expands upon this way of thinking in relation to collective revolutionary violence. She believes that political violence is determined by the existing class division, especially when it is strong, or if the social structure is inefficient. This concept is subject to criticism due to the absence of psychological, individual factors (Skocpol, 1979, pp. 280-281; 1994). Data from empirical studies of the phenomenon of violence performed in the last decades of the twentieth century have undermined this view. It is individuals and groups linked through strong social ties at different levels (friendship ties, memberships in various organizations) that are most inclined to use force (Barkan \& Snowden, 2001, p. 20).

The so-called Misery Thesis is being developed, in which poverty and oppression are considered the most important factor in violence on the basis of social sciences (Sederberg, 1994, pp. 106-107). For Marx the primary determinant for the use of force in society is the fact that a particular group becomes aware of its absolute deprivation - the more the masses are aware of their real interests, and, consequently, the more they question the legitimacy of resource distribution, the more likely it is that the disadvantaged layers will begin to organize a collective opposition against the dominant segments of society. The main condition is the unequal distribution of resources (Turner, 2004, pp. 178-179). This hypothesis was subject to attempts of empirical verification by Hovland and Sears (1940, pp. 301-310). In their pioneering study, they attempted to demonstrate that there is a positive correlation between the number of acts of violence and low economic indicators. Empirical verification has not confirmed this hypothesis (Grimshaw, 1972, p. 40), however, later works link political violence with determinants of an economic nature. Gurr's classical hypothesis has been confirmed (1968). Economic inequality was pointed out as a major determinant of political violence and was measured by quantitative, objective variables, such as gross domestic product ratio (GDP) or the Gini index (Alesina \& Perotti 1996; Caruso \& Schneider 2010; Dutt \& Mitra, 2008; Murshed \& Gates, 2005).

\section{Cultural Determinants of Violence in Politics}

The phenomenon of violence is considered within a cultural perspective, focusing on fixed patterns of actions existing in the community and arising out of sanctioned values, beliefs and attitudes provided in the course of socialization. Violence can be determined by cultural factors: the existing and positively sanctioned belief that it is an effective way of achieving social and political objectives in a particular society (Gurr, 1970, p. 13). In general, researchers focus on one of three factors that can potentially generate violence: micro-social factors (a kind of socialization of individuals and groups for use of violence), macro-social factors (socio-historical, and even anthropological determinants of violence) or factors accentuating the effects of contact between different cultures (examining the phenomenon of violence in terms of culture shock, the clash of civilizations).

Within the micro-social approach the causes of violence are listed as defective socialization within the family group: a broken, disorganized family, unbalanced family life, lack of interest from the family (support, love, acceptance), exposure to domestic violence, neglectful or excessively severe parents, inadequate or overly severe punishment, fierce 
sibling rivalry with a strong feeling of jealousy, sexual abuse by parents, religious or cultural standards in the home leading to a faulty ingraining of moral norms, prohibitions, rules. Faulty socialization in small social groups may also be an important factor in violence: the acceptable impact of a subculture of violence, identification or loyalty towards perpetrators of violence, admiration for gangsters and fraudsters, early and prolonged hospitalization or a stay in a total institution, absorption of violence patterns from the media without the occurrence of condemning, contradictory, or educational factors, or exposure to harsh treatment by law enforcement (Guerra \& Huesmann 2004; Hartogs, 1970, pp. 334-335). This is explained by the concept of an authoritarian personality by Adorno (Grimshaw, 1972, p. 41; Suedfeld 2001; Suedfeld \& Schaller 2002). The basis of an authoritarian personality, for which one of the behavioral manifestations is authoritarian aggression, lies in a specific style of socialization based on conservative methods of upbringing - among these, a deficit in fulfilling emotional needs, harsh, undeserved or inappropriate punishment. This results in strong anti-social attitudes - so-called displaced aggression - from educators to weaker groups (e.g. minorities) (Adorno et al., 2010, pp. 37-114). Papers covering the issue of an authoritarian personality are counted in the hundreds, as various aspects of this issue have been explored by many authors within psychology, sociology and political science (Smolik, 2008). Cultural determinants of violence are sought in the newer concepts relating to the search for identity, social constructionism or the social constructionist perspective. Social constructionism members are considered to include Klandermans (1984, pp. 583-600), Snow and Oliver (1995, pp. 571-599), Zurcher and Snow (1981, pp. 447-482) and presently by Kukla (2000) and Elder-Vass (2012). It focuses on cultural factors, religious among others, as well as on the phenomenon of constructing a collective identity for actions taken by groups of individuals. Collective identity is considered to be a key element in these concepts, as it is seen to constitute an extended personal identity; this is shaped on the basis of joint action, with emotional ties being dominant (Barkan \& Snowden, 2001, pp. 25-27).

Many researchers point to macro-social determinants of violence within the cultural approach - particular patterns or values that are sanctioned by the dominant culture and stimulate individuals to take violent action. Observed and numerous differences between societies in the scope, style, frequency and intensity in the level of violence used in them were the impulse for the emergence of the cultural approach in the search for determinants of violence (Gurr, 1970, pp. 160-161). Within this concept, it is emphasized that violence is determined by the unique historical experiences of a particular culture. For example, in the United States social sciences use, among others, the "frontier theory" and the concept of the key role of firearms in the creation of the American state (the "gun theory") (Nieburg, 1969, p. 22). These are approaches normalizing acts of violence, declaring them to be acceptable, making them part of the culture. Minority activist Brown (actually Jamil Abdullah Al-Amin, also known as H. "Rap" Brown) introduced "The Cherry Pie Thesis" to journalism. He emphasized that violence is everywhere and has a positive effect; it is as popular in the United States as cherry pie: the Union was protected thanks to violence, thanks to violence territories were taken away from indigenous peoples, thanks to violence conflict in the society of early capitalism was suppressed - it permeates the history and social relations of the country (Sederberg, 1994, pp. 103-104). A similar position concerning the introduction of 
violence to the dominant culture due to a combination of extraordinary historical circumstances was taken by Fanon, an ideologist of decolonization, who in his book-manifesto The Wretched of the Earth points to the psychopathological conditions of the process of colonization - the creation of a kind of culture of violence by the colonists. According to this author, colonizers not only seized the territory of the natives by force, but also introduced social relations characterized by constant tension, hostility and contempt. Relations with those colonized were relations of pure violence. The formation and preservation of colonies were accompanied by violence, with the natives nolens volens learning to apply it. Without knowing it, the colonizers created a culture of violence, they pointed out a way of solving social problems and political issues through force to the colonized. The consequence of this reasoning by Fanon $(1985$, pp. 23, 31) is the statement that decolonization can occur only through the use of violent actions - through a kind of imitation of patterns observed and assimilated by the natives.

Some researchers consider that the cultural determinants of violence are not embedded in one period or historical event, but in the entire cultural system. Such a hypothesis was formulated by Durkheim (1992, p. 53) in his early works. He believed that war is characteristic of not fully formed social creations - agrarian, pre-modernist societies - but with the development of humanity, systems of social control become stronger and wars increasingly rare. In this regard Fromm's deliberations set forth in The Anatomy of Human Destructiveness, first published in 1973, can play the role of a synthetic guide. He notices the multidimensionality of the problem of human violence and indicates two of its major sources - biological and cultural. An in-depth interpretation of Fromm's thoughts was performed in Poland by Chałubiński (1992, pp. 90-98). Fromm used secondary sources to perform an analysis of thirty primitive cultures in the context of their use of violence. He used the data collected by, among others, Benedict, Mead, Murdock, Turnbull, distinguishing the following three types of cultures: life-affirming societies, non-destructive-aggressive societies and destructive societies. The fundamental value of life-affirming cultures is the preservation and development of life in all of its forms. Hostility and violence are present in such societies to a minimum degree. There is no harsh, cruel punishment, the crime rate is low and war is waged in very rare circumstances or is unknown. This is usually a culture of permissiveness, of relative equality. Such societies are collectivist. They may include both relatively affluent, as well as poor societies. On the other hand, in non-destructive-aggressive societies violence, war, hierarchy and individualism are the norm. These are cultural systems geared for competition, the completion of tasks, setting challenges. Mutual violence and cruelty are characteristic traits of destructive societies. They manifest themselves both inside and outside the tribe. Life is based on hostility, tension and fear. There is strong competition, a focus on private property, a strict hierarchy, visible warmongering tendencies. The differences between these cultures are, according to Fromm, so significant and important that it is impossible to explain them through biology, features common to all mankind. Both rational, as well as irrational violence can be included in the construction of a particular culture. Fromm refers to differences arising on an anthropological basis that pertain to the determinants of violence. He indicates that there is a lack of synthetic studies of this phenomenon and examines two opposing approaches - those of Freeman and Helmuth (Fromm, 2007, pp. 182, 183-184, 
193-194). Freeman (1964) points out that violence is widespread in primitive societies. Helmuth (1967, pp. 265-273) takes the opposite point of view - he forces the hypothesis of the "peaceful savage". This dilemma is of great importance in the context of Fromm's anthropological ideas (Fromm, 1994; 1996; 2000). As Chałubiński (1992, pp. 97-98) explains, Fromm's ideas were essentially optimistic in tone, because he perceives violence that is destructive and pathological in nature as a product of modern culture and not an inherent biological trait of the human race. If the hypothesis of the "peaceful savage" proved true, modern European culture could be reasonably regarded as degenerate and pathological, as it allows and even glorifies violence in interpersonal relations. It seems that contemporary anthropology solved this dilemma by taking an approach based on universality of violence in primitive societies, while indicating that it is from the human biological propensity for violence that cultural patterns of its use arise. Idealizing the past, seeing prehistoric times as a situation, in which violence occurred extremely rarely, with humans co-existing with other representatives of their species in a peaceful manner, has proved to be a scientific romantic myth (Kaniowska, 2003, p. 180). The book War Before Civilization: The Myth of the Peaceful Savage was written to deal with this assertion. The author cites an interesting quantitative comparison of societies from the Western cultural sphere and pre-state societies in terms of the number of deaths caused by violence. A statistical comparison of the percentage of deaths in relation to the total population shows that, despite the genocide of World War II, modern societies such as Germany, Russia, France or Japan are actually more peaceful than primitive tribes (Keeley, 1997, p. vi). Contemporary research confirms the hypothesis formulated above (LeBlanc \& Register, 2003), however, the thesis of the "noble savage" has many defenders today - a systematic list of arguments with the extensive literature on the subject was presented by Godesky (2007).

The limited length of this paper does not allow for a broader look at the anthropological perspective, but it is worth citing the works that contributed to the refutation of the "peaceful savage" paradigm coming from Diderot, de Montaigne, de Ronsard, Rousseau in this discipline. The works of American anthropologist Chagnon (1968a /1968b, pp. 109-159) on the culture of Yanomamö Indians (also known as Waika, Sanema, Xirana, Guaharibo) are seen as a particularly valuable study of the determinants of violence. Interesting explanations can be found in the study by Mead (1986) of the New Guinea Mundugumorow tribe and the work of Turnbull (1980) based on many years of observations of the African Ik tribe living in the mountains on the border between Uganda, Sudan and Kenya.

An important area for consideration in contemporary social science is the search for cultural determinants of violence versus different cultural agendas. This way of thinking is also present in political science, in the framework of international relations. From this perspective, violence is viewed as a phenomenon generated by culture, with even the form of violence used is being determined by this culture. For example, the conquistadors had an advantage over the Aztecs, as the former strove to eliminate the enemy during battle, while the latter to take them into slavery, which resulted from different cultural patterns of rationality (Malešević, 2010, pp. 64-70). The immediate factor that causes violence is the inability to communicate between groups, a difference in value systems that is impossible to overcome as a result of this force must be used to resolve the conflict (Król, 2008, p. 272). Malešević 
refers to this approach as the culturalist perspective, and mentions Spengler (2001) and Toynbee (2002) as its pioneers. Huntington, who published his thoughts on the subject in the widely discussed book The Clash of Civilizations (Huntington, 1994; 2007) is a contemporary representative of this approach. The geopolitical concept of the author formulated in the first half of the nineties states that, in the event of the disappearance of a bipolar model of international relations, political and ideological divisions, as well as economic inequalities, cease to be an important source of conflict and ultimately violence. He indicates that conflicts based on culture between global civilizations take their place (Huntington, 1994, p. 69). This concept is particularly relevant in light of the terrorist attacks of September 11, 2001, the invasion of Iraq in 2003 and its occupation, and the intervention in Afghanistan ongoing since 2001. The fundamental problem of the inability of different cultures to communicate, a clash of different cultural patterns of rationality has already been indicated by Fanon in the context of decolonization and national liberation policies. According to this, author the basic condition that makes violence indispensable is the inability of the parties to reach agreement; this is because the colonized is not a partner for the colonizer, is consistently denied not only equal treatment, but even humanity - and at that point any communication can be carried out only in terms of strength:

The colonized [...] laughs hearing the words, according to which he is an animal. He knows that he is not. When he discovers this, he reaches for a weapon, with the aim of ensuring the triumph of humanity. [...] the colonized at the very mention of Western civilization pulls out a machete, or at least checks that he has one at hand.

[Fanon, 1985, p. 25].

In a research context the concept of "primordial" violence is used, meaning violence that is racial or religious. This is a violence that stems from conflicts between basic cultural patterns. The increase in the severity of cases of such violence after World War II was pointed out, which is connected with globalization processes. This phenomenon was greatest in strength in Africa during the Tutsi-Hutu fighting (Bayar, 2009). The approach that recognizes cultural determinants as most important is continued in the ethnic competition model created in the seventies and expanded during the next two decades. This model explains that cultural, ethnic divisions are a prerequisite, but are not sufficient for the existence of collective violence; it also includes numerous structural determinants (Barkan \& Snowden, 2001, pp. 22-23).

\section{Individual (Socio-Psychological) Determinants of Violence In Politics}

This movement seeks to explain the causes of violence from the perspective of an individual; researchers consider why some individuals engage in activities related to violence, and others - caeteris paribus - do not (Barkan \& Snowden, 2001, p. 14). The search for sources of violence focuses on emotional factors, affective motives and subjective inner experiences of the individual. This is an individualistic perspective, which refers to subjective factors. It is often (although not always) accompanied by a pessimistic anthropological perception of a human being. A genetic determinant for human violence is accented. Researchers in this approach are very happy to rely on philosophical sources (which are synthetically represented by the Hobbesian aphorism homo homini lupus est (Hobbes, 2000), along with its considered in the Leviathan - implications, or on sociobiology and evolutionary psychology, in particular the hypothesis of killer-monkeys. Our defective human nature is the source of 
violence, while culture and social structure are the guardians of order; they were created to curb the criminal tendencies of human beings. Although today it is emphasized that this way of thinking makes humans one-dimensional, that it is an excessive and unacceptable simplification, there is still a tendency to explain the phenomenon of violence in these categories (Sederberg, 1994, p. 103).

Originally, researchers examining personality based determinants of violence, perceived the phenomenon of violence as socially senseless, pathological, a sign of the madness of an individual (Apter, 1997, p. 7). The "senselessness" of violence can be understood in three ways. Firstly, one can treat violence as irrational in the sense that this phenomenon was caused by random factors, an accident; secondly, "senseless" may mean actions of irrationally thinking individuals (insane, under the influence of psychoactive substances, subject to powerful stress or possessed by a demon); and thirdly, as an act performed without moral reflection, without regard for the consequences (Ball-Rokeach, 1972, pp. 89-90). The belief in the irrationality of violence lies in a deep, well-established, popular, everyday belief on this subject. Notice that the Catholic Trisagion "Save us Lord, from Air, Famine, Fire and War" locates the phenomenon of violence among unknown, random factors, upon which an ordinary man cannot have any influence (Hanasz, 1991, p. 8). Proponents of this interpretation can be found in particular in psychoanalytic theories (Van der Dennen, 2005). The irrationality of violence-related activities was indicated by Freud (1967). According to the psychoanalytic concept, the inclination of an individual to use violence is strongly correlated with his or her traumatic experiences of early childhood, in particular sexual trauma, which is the most important (Grimshaw, 1972, p. 40). There is also no rational explanation through psychoanalysis for collective violence - the crowd reasons like a child or a primitive entity (Barkan \& Snowden, 2001, p. 15). Some followers of Freud have made a number of interesting theoretical attempts when analyzing the phenomenon of violence. For example, Feuer (1969) considered this issue in the context of the Oedipus complex by subjecting concrete manifestations of violence to research. Proponents of the psychoanalytic concept stated that such actions were seen by those taking part in them as more expressive than instrumental, as emotional, disorganized and devoid of rules. As a result, they refused to include them in political categories, because they were not aimed at achieving collective benefits, but individual gratification in the form of releasing emotional tension (Barkan \& Snowden, 2001, p. 16). Analogous opinions were expressed by Le Bon (1997, p.7), who is to be found within this trend of reflections on violence, who also emphasized the crowd's low reasoning ability and their great capacity for action. German sociologist and historian Wolfgang Sofsky (1999, pp.46-65) sees violence as non-instrumental and meaningless. The author examines the historical example of the criminal activity of Gilles de Rais, concluding that some of the violence may not have any teleological, instrumental explanation. Efforts are being made to recognize and classify the individual factors of violence on the basis of psychology. Such an attempt was made by, among others, Hartogs (1970, pp. 335-336), when he gave an enumerative list of twelve psychological factors for conditioning violence: impulsiveness, emotional instability, faulty psycho-sexual development, difficulties in interpreting the social world, inability or difficulty in adapting to new conditions, the need for immediate gratification, hypersensitivity. Apart from psychological conditions he also lists 
organic conditions, including short-term factors: alcoholism and drug addiction, long-term factors: excessive secretion of endocrine glands, the tendency to combine sex and aggression, persistent nocturnal enuresis, neuromuscular excitability and permanent factors: brain damage, particularly of the temporal or parietal areas, dysfunctions such as epilepsy, especially psycho-motor epilepsy, physical disability or fear of a disease, inherited tendency to violence. Therefore violence arises from an impaired, through various factors, faulty perception of the social world and should not be exhibited by healthy individuals.

The theory of senseless violence is colloquially known in American social science as the "riffraff theory" (Nieburg, 1969, p. 20). Such a view of the determinants of violence is not only the domain of psychology - American mainstream sociology has developed an approach referred to as "irrational", popularized by Parka and other well-known sociologists from the University of Chicago. They began the tradition of research on collective behavior. They saw riots, revolts, and other violent actions as non-institutional forms of collective behavior. Such events are a sign of the collapse of social norms and the expression of a breakdown in standards of normal social behavior. Researchers point out that the historical condition for the concept of the irrationality of violence was a series of traumatic historical experiences across Europe - beginning with the French Revolution and World Wars - and the phenomenon of political terrorism. The experience of shocks, disturbances, the elusiveness of social order have led to the recognition of activities related to violence as being irrational. With the beginning of the seventies, criticism of this concept began. It grew on the basis of political events that took place at the time: the Civil Rights movement activities and the anti-war movement against the Vietnam War in the United States, as well as the social changes taking place around the world. Researchers refused to analyze liberation seeking movements - using moderate violence - as senseless, illogical, futile, resulting from internal selfish motives of the participants, while looking for other explanations. This new way of explaining the phenomena became known as the resource mobilization theory, drawing attention mainly to structural considerations (Barkan \& Snowden, 2001, pp. 14-15, 17). Król (2008, pp. 271-272) indicates the dangerous consequences of such thinking about the phenomenon of violence assuming human irrationality leads to an elitist current in political philosophy. If people are irrational by nature then they are not able to make good political decisions, and therefore the more enlightened rulers should impose them by force.

Within the trend focusing on individual determinants of violence there is an approach alternative to the view that sees use of force in human relations as futile; this examines violence as a rational choice of an individual taken on the basis of the calculation of potential gains and losses (Apter, 1997, p. 7). The explanation of the phenomenon of violence is done in terms of economic rationality, it is an instrumental, utilitarian approach. It is assumed that the use of violence is very expensive, as it entails a range of negative sanctions and is undertaken only if the possible benefits can be higher than any potential loss, or where the probability of obtaining a prize is much higher than that of receiving punishment. Such an action is therefore conscious, thought through and generally serves some interests (Ball-Rokeach 1972, p. 107; Malešević, 2010, pp. 58-64). This approach is originally derived from the ideas of de Montesquieu and Smith. This view was also being developed on the basis of Marxism (Marks, 1968) and Neo-Marxism (Turner, 2004, pp. 178-179), while in 
contemporary discourse this viewpoint is present in the theory of rational choice. Among others, Kalyvas (2006) is a contemporary representative of this type of approach. The perspective of rational choice is not dedicated to explaining violence in society, but can serve this goal, as well as be used for examining other social phenomena.

The greatest popularity is currently enjoyed, from among rational socio-psychological explanations, by an approach called the "deprivation-frustration-aggression", or "frustration and relative deprivation", or, in short the frustration-aggression theory (Coser, 1967, pp. 56, 59; Davies, 1962, pp. 5-19). This perspective developed within the framework of the conflict theory, one of the first sociological theoretical orientations (Gurr, 1970, p. 24). The basic premise of this concept is that a so-called sense of relative deprivation may be formed in the psyche of the individual based on the observation of the environment and comparison with other individuals and social groups (if the result of the comparison in accordance to some social aspect of it is negative and, consequently, the individual decides that he or she fares worse than those with whom they are comparing themselves) or relative privilege (if the result of such a comparison is positive and the individual finds that his or her social position is more favorable than of those similar). The sense of relative deprivation - that is the impression of a relative, subjective (and perhaps non-existent in fact) deficiency - is the primary factor in explaining the use of violent actions. The key social values in the process of the individual's comparison with the social environment are mainly: economic prosperity, power and interpersonal relationships (Barkan \& Snowden, 2001, p. 17; Gurr, 1970, p. 25). This theory was developed in the late thirties of the twentieth century by psychologist John Dollard and his associates. The very concept of relative deprivation appeared for the first time in the works of Stouffer (1949), American sociologist and one of the pioneers of quantitative research techniques. Stouffer and his colleagues tested more than half a million American soldiers during World War II and, on the basis of these studies, formulated the thesis on the mechanism of comparisons between the individual and his or her social environment. A milestone of this theory was the article published by Davies (1962, pp. 5-19). The concept of relative deprivation within research on violence was developed by Gurr in 1970. It is still current and is still being developed (Walker \& Smith, 2002, pp. 1-12). It has become very popular with many researchers alluding to it, but - as some argue - in an oversimplified way (Gurney \& Tierney, 1982, pp. 33-47; Rule, 1988; Salert, 1976; Sederberg, 1994). Gurr (1970, pp. $12,13,52-56,103-105,105-109,210,211)$ argues that some element of rationality is to be found in every political or social phenomenon. He emphasizes that individuals rationally verify profit and loss, and are motivated more by particular goals other than social. An action with the use of violence consists, in each case, of the following three phases: a sense of dissatisfaction, the "politization of discontent" and commencement of violent actions. Relative deprivation is the primary determinant of dissatisfaction. It is understood as the perceived contradiction between the expectations of individuals and the actual implementation of these expectations in the course of the social processes in which the individual participates. Gurr believes this type of deprivation to be elementary stimulus for an individual to take action. He stresses that similar conclusions are drawn on the basis of the conflict theory - the higher the dissatisfaction, the higher the intensity of violence. Exposure to new styles of life, emergence of new ideologies and new groups of reference are all 
subjective factors of relative deprivation. Gurr distinguished three types of social determinants of violence. In the first case violence can occur when social expectations of individuals remain at the same level, but the possibility of their implementation is reduced. This situation is referred to as decremental deprivation (Gurr, 1970, pp. 46-50). Violence may also be a result of aspirational deprivation. This occurs as a result of an individual's increased expectations under the influence external stimuli, while still having the same possibilities to meet expectations (Gurr, 1970, pp. 50-52). In turn, progressive deprivation occurs as a result of simultaneous growth of aspirations and opportunities for realization for the individual, with the former growing faster than the latter (Gurr, 1970, pp. 52-56).

The concept of relative deprivation is subject to criticism in literature on the subject. Emphasis is placed mainly on the fact that it was not duly confirmed through empirical studies, as the material provided for analysis is limited to examples in temporal and geographical terms - riots in the United States in the sixties of the twentieth century (Barkan \& Snowden, 2001, p. 18). Newer studies, however, demonstrate that the emergence of violence also depends on factors other than the subjective feeling of deficiency (Goode, 1992, p. 127; Muller, 1979). Despite criticism, this concept still has many supporters and defenders. Snow and Oliver state that the process of empirical testing of this concept was defective and therefore lead to distorted results. They propose a different method for measurements, more adequate for this concept, based on awareness factors (Snow \& Oliver, 1995, p. 579).

Researchers of socio-psychological determinants of political violence more often use new research methods derived from medical science and combine them with the experimental methods. These new methods include electrical brain activity testing (electroencephalography, EEG), measuring of magnetic brain activity (magneto encephalography, MEG), as well as examining metabolic changes processes of the brain using positron emission tomography (positron emission tomography, PET) or with functional magnetic resonance imaging (fMRI) (Schlögl, Slater \& Pfurtscheller, 2002; Szymusiak 2012). The results of these studies suggest that the behavior of individuals is conditioned by lack of consciousness processes that take place at the neural level. Such a view, in terms of ontology, is called epiphenomenalism feelings and thoughts are merely secondary phenomena of physical and chemical states of the brain, and are not real, autonomous processes (Dopfer, 2004; Ohme, 2008; Sanfey, Rilling, Aronson, Nystrom \& Cohen, 2003; Žaltman, 2003). Socio-psychological determinants of violence are also examined in the field of evolutionary psychology, especially conducted a comparative study of man with other social animals, and on the basis of genetics (Ramirez, 2010a; 2010b, 2010c, 2010d).

\section{Conclusion}

The phenomenon of the determinants of political violence is tested in numerous disciplines of the social sciences and humanities. A study of the literature carried in the article makes sure that research is the main factor influencing the identification of determinants of political violence. Researchers of sociology and political science are those who almost exclusively point to the structural determinants of violence. In turn, the prospect of cultural determinants of violence is accepted in disciplines such as: anthropology, cultural studies, education and partly also sociology and history. Socio-psychological determinants of political violence are closest to psychology, including social psychology. This condition of the identification of 
methods and paradigms of the discipline results in an error of particularity; reflection on political violence is fragmented, researchers are limited to a few methods specific to their discipline. Meanwhile, in the case of political violence, we can talk about multi-causal determinism, because political violence is induced by the convolution of many factors. Recognition of this syndrome and prioritization factors constituting it, seem to be a natural next step in research on the determinants of violence. The results of such a reflection would have not only cognitive, but also prognostic value. The implementation methodology of such an interdisciplinary study of complex problems beyond one discipline research was postulated by Wilson (1998), by giving it the name "consilience".

Attention should also be paid to the similarities and differences between the determinants of violence in the range of ethical issues. Researchers of structural determinants of violence in contrast to the other two trends seem to justify violence, indicating that it is one of the factors of political and/or social change and can be both eufunctional, as well as dysfunctional. Hence, this is where the dangerous dualism in Western culture referring to the perception of political violence stems from. On the one hand, we clearly and unconditionally condemn any manifestation of violence and fear it, which is visible in the extensive care taken in formulating thoughts about it, and even its marginalization in the sphere of social and philosophical thought. On the other hand we are dealing with the phenomenon of abuse and the standardization of violence in political practice. European culture developed through external violence in the form of conquest, wars, colonialism, exploitation and internal violence - on the basis of political and social revolutions, coups and ethnic conflicts. The Janus-face of Western culture is exposed by, among others, Chomsky (1999) in Year 501: The conquest continues. His opinion is echoed by Gray, British philosopher and political scientist (2009, pp. 48-49; Pepinsky, 1991 p. ix), who points out that the French Revolution, in addition to noble slogans of freedom, equality and fraternity brought with it the never lost faith in the cleansing power of war and terror. It opened the era of political murders in European history and the Jacobin inspired policy intensified in the twentieth century to an extent hitherto unprecedented in human history, and continues until today, despite assurances that violence is the antithesis of democracy.

\section{Acknowledgements}

The research is financed by Instytut Badań nad Człowiekiem i Społeczeństwem im. Elżbiety Mider z d. Korzun, ul. Meander 12 m. 38, 02-791 Warszawa.

\section{References}

Adorno, T. W., Frenkel-Brunswik, E., Levinson, D. J., \& Stanford, R. N. (2010). Pomiar ukrytych dyspozycji antydemokratycznych [The Measurement of Implicit Antidemocratic Trends]. In T. W. Adorno, Osobowość autorytarna [The Authoritarian Personality]. Warsaw: Wydawnictwo Naukowe PWN. (Original work published 1950).

Alesina, A., \& Perotti, R. (1996). Income Distribution, Political Instability, and Investment. European Economic Review, 40, 1203-1228. http://dx.doi.org/10.1016/0014-2921(95)00030-5 Apter, D. E. (1997). Political Violence in Analytical Perspective. In D. E. Apter (Ed.), The Legitimization of Violence. New York: New York University Press. 
Arendt, H. (1988). Tradycja a epoka nowoczesna [Tradition and the modern age]. Res Publica, 9

Aristotle. (1956). Etyka nikomachejska [Nicomachean Ethics] (D. Gromska, Trans.) Kraków: Państwowe Wydawnictwo Naukowe. (Original work published 350 BC).

Aristotle. (1996). Metafizyka [Metaphysics], (T. Żeleźnik, Trans.). Lublin: Redakcja Wydawnictw Katolickiego Uniwersytetu Lubelskiego. (Original work published 350 BC).

Ashworth, C., \& Dandeker, C. (1987). Warfare, Social Theory, and West European Development. Sociological Review,

Ball-Rokeach, S. J. (1972). The Legitimation of Violence. In J.F. Short Jr., \& M.E. Wolfgang (Eds.), Collective Violence. Chicago: Aldine Atherton.

Barkan, S. E., \& Snowden, L.L. (2001). Collective Violence. Boston: Allyn \& Bacon.

Bayar, M. (2009) Reconsidering Primordialism: an alternative approach to the study of ethnicity, Ethnic and Racial Studies, 32.9, pp. 1-20.

Bergson, H. (1988). Dwa źródła moralności i religii [The two sources of morality and religion]. In I. Wojnar (Ed.), Utopia w perspektywie pedagogicznej [Utopia in pedagogical perspective]. Warsaw: Wydawnictwa Uniwersytetu Warszawskiego.

Bill, J. A. (1973). Political Violence and Political Change: A Conceptual Commentary. In H. Hirsch, \& D. C. Perry (Eds.), Violence as Politics. New York, Evanston, San Francisco, London: Harper \& Row Publishers.

Blomberg, S. B., Hess, G. D., \& Weerapana, A. (2004). Economic Conditions and terrorism, European Journal of Political Economy, 20(2), 463-478. http://dx.doi.org/10.1016/j.ejpoleco.2004.02.002

Błuszkowski, J. (2007). Paradoksy normalności i dewiacji [Paradoxes of normality and deviance]. In J. Błuszkowski, Paradoksy polityki. Warsaw: Elipsa.

Burgoon, B. (2006). On welfare and terror: Social welfare policies and political economic roots of terrorism. Journal of Conflict Resolution, 50, 176-203. http://dx.doi.org/10.1177/0022002705284829

Caruso, R., \& Schneider, F. (2010). The Socio-Economic Determinants of Terrorism and Political Violence in Western Europe (1994-2007). http://dx.doi.org/10.2139/ssrn.1693876

Chagnon, N. A. (1968a). Yanomamö. Social Organization and Warfare. In M. Fried, M. Harris, \& R. Murphy (Eds.), War. The Anthropology of Armed Conflict and Aggression. New York: The Natural History Press.

Chagnon, N. A. (1968b). Yanomamö. The Fierce people, Holt. New York: Rinehart and Winston.

Chałubiński, M. (1992). Antropologia i utopia. Jednostka a społeczeństwo w pogladach Ericha Fromma [Anthropology and utopia. Individual and Society in the views of Erich Fromm]. Warsaw: Scholar.

Chomsky, N. (1999). Rok 501. Podbój trwa [Year 501: The Conquest Continues]. Warsaw, Poznań: Wydawnictwo Naukowe PWN.

Coser, L. A. (1967). Internal Violence as a Mechanism for Conflict Resolution. In L. A. Coser, Continuities in the Study of Social Conflict. New York: The Free Press. 
Czarnowski, S. (1982). Ludzie zbędni w służbie przemocy [People expendable in the service of violence]. In S. Czarnowski, Wybór pism socjologicznych [Choose of sociological writings]. Warsaw: Książka i Wiedza.

Czyżewski, M. (2003). Trzy nurty socjologii przemocy jako odmiany dyskursu - o pułapkach czynienia przemocy wytłumaczalna [The three strands of the sociology of violence as a variety of discourse - About the pitfalls faced violence explainable]. Przeglad Socjologiczny. LII, 1. Łódź: Łódzkie Towarzystwo Naukowe.

Davies, J. C. (1962). Toward a Theory of Revolution. American Sociological Review, 27. http://dx.doi.org/10.2307/2089714

Dopfer, K. (2004). The Economic Agent as Rule Maker and Rule User: Homo Sapiens Economicus, Journal of Evolutionary Economics, 14.

Durkheim, E. (1992). Professional Ethics and Civic Morals (2nd ed.). London: Routledge \& Kegan Paul. (Original work published 1958).

Dutt, P., \& Mitra, D. (2008). Inequality and the Instability of Polity and Policy. The Economic Journal, 118. http://dx.doi.org/10.1111/j.1468-0297.2008.02170.x

Elder-Vass, D. (2012). The Reality of Social Construction, Cambridge: Cambridge University Press. http://dx.doi.org/10.1017/CBO9781139169202

Fanon, F. (1985). Wyklęty lud ziemi [The Wretched of the Earth]. Warsaw: Państwowy Instytut Wydawniczy.

Feuer, L. S. (1969). The Conflict of Generations. New York: Basic Books.

Freeman, D. (1964). Human Aggression in Anthropological Perspective. In J. D. Carthy \& F. J. Ebling (Eds.), Natural History of Aggression. New York: Academic.

Freud, Z. (1967). Group Psychology and the Analysis of the Ego (6th ed.). New York: Liverwright Publishing.

Fromm, E. (1994). Wojna w człowieku: psychologiczne studium istoty destrukcyjności [War within man: A psychological enquiry into the roots of destructiveness], (P. Kuropatwiński, P. Pankiewicz, \& J. Węgrodzka, Trans.). Warsaw: Jacek Santorski \& CO Agencja Wydawnicza. Fromm, E. (1996). Zdrowe społeczeństwo [The Sane Society], (A. Tanalska-Dulęba, Trans.). Warsaw: Państwowy Instytut Wydawniczy.

Fromm, E. (2000). Serce człowieka: jego niezwykła zdolność do dobra i zła [The Heart of Man: Its Genius For Good and Evil], (R. Saciuk, Trans.). Warsaw, Wrocław: Wydawnictwo Naukowe PWN.

Fromm, E. (2007). The Anatomy of Human Destructiveness, (J. Karłowski, Trans.). Poznań: Rebis.

Gamson, W. A. (1992). The Social Psychology of Collective Action. In: A. D. Morris, \& McClurg Mueller, C. (Eds.), Frontiers in Social Movement Theory (pp. 53-76). New Haven: Yale University Press.

Gameson, W. A. (1975). The Strategy of Social Protest. Homewood: Dorsey Press.

Godesky, J. (2007). The Savages are Truly Noble [Online] Available: http://tobyspeople.com/anthropik/2007/05/the-savages-aretruly-noble/ (August, 20, 2009).

Goode, E. (1992). Collective Behavior. Fort Worth: Harcourt Brace Jovanovich. 
Gray, J. (2009). Czarna msza. Apokaliptyczna religia i śmierć utopii [Black Mass: Apocalyptic Religion and the Death of Utopia], (A. Puchejda, \& A. Szymaniak, Trans.). Kraków: Znak.

Grimshaw, A. D. (1972). Interpreting Collective Violence: An Argument for the Importance of Social Structure. In J. F. Short Jr., \& M. E. Wolfgang (Eds.). Collective Violence. Chicago: Aldine Atherton.

Guerra, N., \& Huesmann, L. R. (2004). Une theorie cognitivo-ecologique du comportement agressif. [A cognitive-ecological model of aggression.] Revue Internationale de Psychologie Sociale

Gurney, J. N., \& Tierney, K. J. (1982). Relative Deprivation and Social Movements: A Critical Look At Twenty Years of Theory and Research. Sociological Quarterly, 23, 33-47. http://dx.doi.org/10.1111/j.1533-8525.1982.tb02218.x

Gurr, T. R. (1968). Psychological Factors in Civil Violence. World Politics, 20, 245-278. http://dx.doi.org/10.2307/2009798

Gurr, T. R. (1970). Why Men Rebel. Princeton: Princeton University Press.

Hanasz, W. (1991). Przemoc: między destrukcją a kreacją [Violence: Between destruction and creation]. In W. Hanasz, \& G. Zalejko (Eds.), Przemoc. W poszukiwaniu interpretacji [Violence. In search of interpretation]. Torun: Uniwersytet Mikołaja Kopernika w Toruniu.

Hartogs, R. (1970). Who Will Act Violently: The Predictive Criteria. In R. Hartogs, \& E. Artzt, Violence. Causes and Solutions. New York: Dell Publishing.

Heitmeyer, W., \& Hagan, J. (Eds.) (2003). International Handbook of Violence Research. Dordrecht: Kluwer. http://dx.doi.org/10.1007/978-0-306-48039-3

Helmuth, H. (1967). Zum Verhalten des Menschen: die Aggression, Zeitschrift für Ethnologie, 92, 265-273

Hirsch, H., \& Perry, D. C. (1973). Introduction. In H. Hirsch, \& D. C. Perry (Eds.), Violence as Politics. New York, Evanston, San Francisco, London: Harper \& Row Publishers.

Hobbes, T. (2000). De Cive, [Online] Available: http://www.unilibrary.com/ebooks/Hobbes,\%20Thomas\%20-\%20De\%20Cive.pdf (March 25, 2014).

Hovland, C.I., \& Sears R.R. (1940). Minor Studies of Aggression: VI. Correlation of Lynchings with Economic Indices. The Journal of Psychology, 9. http://dx.doi.org/10.1080/00223980.1940.9917696

Hughes, B. (2004). Political Violence and Democracy: Do Societal Identity Threats Matter? The Security and Politics of Identity, [Online] Available: http://www.adelaide.edu.au/apsa/docs_papers/Others/Hughes.pdf (March 26, 2014)

Huntington, S. P. (1994). Wojna cywilizacji? [The Clash of Civilizations?]. Res Publica Nowa. (65), 2

Huntington, S. P. (2007). Zderzenie cywilizacji [The Clash of Civilzations]. Warsaw: Muza.

Internationales Handbuch der Gewaltforschung [International Handbook of Violence Research]. Opladen: Westdeuscher Verlag, 2002.

Kagan, R. (2003). Potega i Raj. Ameryka i Europa w nowym porzadku świata [Of Paradise and Power: America and Europe in the New World Order]. Warsaw: Emka. 
Kalyvas, S. N. (2006). The Logic of Violence in Civil War. Cambridge: Cambridge University Press. http://dx.doi.org/10.1017/CBO9780511818462

Kaniowska, K. (2003). Przemoc jako przedmiot badań w antropologii [Violence as a subject of study in anthropology]. Przeglad Socjologiczny [Sociological Review]. LII. 1. Łódź: Łódzkie Towarzystwo Naukowe

Keane, J. (2004). Violence and Democracy. Cambridge: Cambridge University Press. http://dx.doi.org/10.1017/CBO9780511756023

Keeley, L. H. (1997). War Before Civilization. The Myth of the Peaceful Savage. New York, Oxford: Oxford University Press.

Klandermans, B. (1984). Social Psychological Expansions of Resource Mobilization Theory. American Sociological Review, 49

Kołakowski, L. (2003). O przemocy [On violence]. In L. Kołakowski, Mini wykłady o maxi sprawach [Mini lectures on matters maxi]. Kraków: Znak.

Król, M. (2008). Filozofia polityczna [Political philosophy]. Kraków: Znak.

Krug, E. G., Dahlberg L. L., Mercy J. A., Zwi A. B., \& Lozano R. (Eds.) (2002). World Report on Violence and Health, World Health Organization, Genewa, [Online] Available: http://www.who.int/violence_injury_prevention/violence/world_report/en/full_en.pdf (June, 2011)

Kukla, A. (2000). Social Constructivism and the Philosophy of Science. London and New York: Routledge.

LeBlanc, S. A., \& Register, K. E. (2003). Constant battles: The myth of the peaceful, noble savage. New York: St. Martin's Press. [Online] Available: http://rewild.info/anthropik/2007/05/the-savages-are-truly-noble/ (March 25, 2014)

Le Bon, G. (1997). Psychologia tlumu [Psychology of Crowds]. Warsaw: Pavo.

Lupsha, P. A., \& MacKinnon, C. (1973). A Sociocultural Perspective on the Nature of Political Violence. Domestic Political Violence, 1965-1971: A Radical Perspective. In H. Hirsch, \& D. C. Perry (Eds.), Violence as Politics. New York, Evanston, San Francisco, London: Harper \& Row Publishers.

Malešević, S. (2010). The Sociology of War and Violence. New York: Cambridge University Press. http://dx.doi.org/10.1017/CBO9780511777752

Marks, K. (1968). Kapitat. Krytyka ekonomii politycznej [Capital. A Critique of Political Economy], t. 1, ks. 1, MED., t. 23, Warsaw.

Mazurkiewicz, P. (2006). Przemoc $w$ polityce [Violence in politics]. Wrocław, Warsaw, Kraków: Zakład Narodowy im. Ossolińskich.

Mead, M. (1986). Trzy studia. 3. Płeć $i$ charakter $w$ trzech społecznościach pierwotnych [Three studies. 3. Sex and Temperament in Three Primitive Societies]. Warsaw: Państwowy Instytut Wydawniczy.

Muller, E. N. (1979). Aggressive Political Participation. Princeton: Princeton University Press. 
Murshed, S. M., \& Gates, S. (2005). Spatial-Horizontal Inequality and the Maoist Insurgency in Nepal. Review of Development $\quad$ Economics, http://dx.doi.org/10.1111/j.1467-9361.2005.00267.x

Nieburg, H. L. (1969). Political Violence. The Behavioral Process. New York: St. Martin's Press.

Ohme, R. K. (2008). Neuromarketing jako owoc mariażu nauki z biznesem [Neuromarketing as a result of the marriage of science and business], Marketing $i$ Rynek, 2, s. 11

Pareto, V. (1994). Uczucia $i$ działania. Fragmenty socjologiczne [Feelings and actions. Sociological parts]. Warsaw: Wydawnictwo Naukowe PWN.

Parsons, T. (1964). Some Reflections on the Place of Force in Social Process. In H. Eckstein (Ed.), Internal War. Problems and Approaches. New York: The Free Press of Glencoe.

Pepinsky, H. E. (1991). The Geometry of Violence and Democracy. Bloomington Indianapolis: Indiana University Press.

Peyrefitte, A. (Ed.) (1982). Spoleczeństwo wobec przemocy. Raport Komitetu Badań nad Przemoca, Zbrodniq i Występkiem [Society towards violence. Report of the Committee for Research on Violence, Crime and Misdemeanors]. Warsaw: Państwowe Wydawnictwo Naukowe.

Piotrowski, A. (2003). Notatki o pojęciu przemocy [Notes on the concept of violence]. Przeglad Socjologiczny [The Sociological Review], LII, 1, Łódź: Łódzkie Towarzystwo Naukowe

Plodowski, A., Gregory, S. L., \& Blackwood, N. J. (2009). Persistent violent offending among adult men: A critical review of neuroimaging studies. In S. Hodgins, E. Viding, \& A. Plodowski (Eds.), The Neurobiological Basis of Violence. Science and Rehabilitation, Oxford University Press, Oxford.

Popper, K. R. (1987a). Spoleczeństwo otwarte i jego wrogowie, Tom 1: Urok Platona [The open society and its enemies. The spell of Plato]. Warsaw: Niezależna Oficyna Wydawnicza.

Popper, K. R. (1987b). Spoleczeństwo otwarte i jego wrogowie, Tom 2: Wysoka fala proroctw: Hegel, Marks i nastepstwa [The open society and its enemies. The high tide of prophecy: Hegel, Marx, and the aftermath]. Warsaw: Niezależna Oficyna Wydawnicza.

Ramirez, J. M. (2010a). Human Aggression: a multifaced phenomenon. Madrid: Centreur

Ramirez, J. M. (2010b). The nature of violence. In J. M. Ramirez, Human Aggression: a multifaced phenomenon. Madrid: Centreur

Ramirez, J. M. (2010c). Animal models in the research of human aggression. In J. M. Ramirez, Human Aggression: a multifaced phenomenon. Madrid: Centreur

Ramirez, J. M., Hinde, R., Groebel, J. (2010d). Human Aggression: a multifaced phenomenon. Madrid: Centreur

Rule, J. B. (1988). Theories of Civil Violence. Berkeley: University of California Press.

Salert, B. (1976). Revolutions and Revolutionaries. New York: Elsvier.

Sanfey, A. G., Rilling, J. K., Aronson, J. A., Nystrom, L. E., \& Cohen, J. D. (2003). The Neural Basis of Economic Decision-Making in the Ultimatum Game, Science, 300, 1755-1758. http://dx.doi.org/10.1126/science.1082976 
Schlögl, A., Slater, M., \& Pfurtscheller, G. (2002). Presence research and EEG. [Online] Available:

http://www-dept.cs.ucl.ac.uk/research/equator/papers/Documents2002/Mel_presence_2002.p df (September, 2013)

Sederberg, P. C. (1994). Fires Within. Political Violence and Revolutionary Change. New York: HarperCollins College Publishers.

Skocpol, T. (1979). States and Social Revolutions: A Comparative Analysis of France, Russia, and China. New York: Cambridge University Press.

Skocpol, T. (1994). Social Revolutions in the Modern World. New York: Cambridge University Press. http://dx.doi.org/10.1017/CBO9781139173834

Smelser, N., \& Swedberg, R. (1994). The Handbook of Economic Sociology. New York: Russell Sage Foundation; Princeton: Princeton University Press.

Smolik, J. (2008). The Influence of the Concept of Authoritarian Personality Today. Central European Political Studies Review, 5(1), 34-48.

Snow, D. A., \& Oliver, P. E. (1995). Social Movements and Collective Behavior: Social Psychological Dimensions and Considerations. In K. S. Cook, \& G. A. Fine, Social Perspectives on Social Psychology. Boston: House J. S., Allyn \& Bacon.

Sofsky, W. (1999). Traktat o przemocy [The Order of Terror]. Wrocław: Wydawnictwo Dolnośląskie.

Sorel, G. (1941). Reflections on Violence. New York: Peter Smith.

Spengler, O. (2001). Zmierzch zachodu. Zarys morfologii historii uniwersalnej [The Decline of the West], (J. Marzęcki, Trans.). Warsaw: Wydawnictwo KR.

Stouffer, S. A., Cochran E., DeVinney L. C., Star S. A., \& Williams, R. M., Jr. (1949). The American Soldier: Adjustment During Army Life. Princeton: Princeton University Press.

Suedfeld, P. (2001). Theories of the Holocaust: Trying to explain the unimaginable In D. Chirot \& M. E. Seligman (Eds.), Ethnopolitical warfare: Causes, consequences and possible solutions (pp. 51-70). Washington, DC: APA Press. http://dx.doi.org/10.1037/10396-004

Suedfield, P., \& Schaller, M. (2002). Authoritarianism and the Holocaust: Some cognitive and affective implications. In L. S. Newman \& R. Erber (Eds.), Understanding genocide: The social psychology of the Holocaust (pp. 68-90). New York: Oxford University Press. http://dx.doi.org/10.1093/acprof:oso/9780195133622.003.0004

Sztompka, P. (2003). Socjologia. Analiza społeczeństwa [Sociology. An analysis of society]. Kraków: Znak.

Szymusiak, H. (2012). Neurobiologiczne techniki stosowane w biznesie, Poznań: Wydawnictwo Uniwersytetu Ekonomicznego w Poznaniu.

Tarrow, S. (1998). Power in Movement: Social Movements and Contentious Politics. New York: Cambridge University Press. http://dx.doi.org/10.1017/CBO9780511813245

Taylor, M. (1991). The Fanatics. A Behavioural Approach to Political Violence. London: Brassey's.

Tilly, Ch. (1978). From Mobilization to Revolution. New York: McGraw-Hill Publishing Company. 
Tiryakian, E. A. (1999). War: The Covered Side of Modernity. International Sociology, 14, 4. http://dx.doi.org/10.1177/0268580999014004006

Toynbee, A. J. (2002). Wojna i cywilizacja [War and Civilisation]. Warsaw: De Agostini.

Turnbull, C. M. (1980). Ikowie ludzie gór [The Mountain People]. Warsaw: Państwowy Instytut Wydawniczy.

Turner, J. H. (2004). Struktura teorii socjologicznej [Structure of Sociological Theory]. Warsaw: Wydawnictwo Naukowe PWN.

Van der Dennen, J. M. G. (2005). Psychoanalytic Theories of Aggression. [Online] Available: http://rechten.eldoc.ub.rug.n1/FILES/root/Algemeen/overigepublicaties/2005enouder/A-PAN AL/A-PANAL.pdf (June, 2011).

Von der Mehden, F. R. (1973). Comparative Political Violence. New Jersey: Prentice-Hall.

Walker, I., \& Smith, H. J. (2002). Relative Deprivation: Specification, Development, and Integration, New York: Cambridge University Press.

Wilson, E. O. (1998). Consilience. The Unity of Knowledge. New York: Alfred A. Knopf.

Žaltman, G.. (2003). How Customers Think: Essential Insights into the Mind of the Markets. Boston: Harvard Business School Press.

Zurcher, L. A., \& Snow, D. A. (1981). Collective Behavior: Social Movements. In M. Rosenberg, \& R. M. Turner (Eds.), Social Psychology: Sociological Perspectives. New York: Basic Books.

\section{Copyright Disclaimer}

Copyright reserved by the author(s).

This article is an open-access article distributed under the terms and conditions of the Creative Commons Attribution license (http://creativecommons.org/licenses/by/3.0/). 